\title{
Entrepreneurship Education in Guangxi Universities Curriculum Development Inquiry
}

\author{
Chen Xianning ${ }^{1,}$, Li Dehua ${ }^{2}$ b* $^{*}$ \\ ${ }^{1}$ Wuzhou College Business School, Wanxiu District, Wuzhou, Guangxi, China \\ ${ }^{2}$ Wuzhou College League Committee, Wanxiu District, Wuzhou, Guangxi, China \\ a983426649@qq.com \\ b*492600953@qq.com
}

\begin{abstract}
As the first region facing ASEAN, Guangxi has more and more frequent economic and trade investment links with ASEAN countries. With the establishment of China-ASEAN Free Trade Area, the demand for talents in the future development of Guangxi will be more inclined to innovative talents. It is necessary for us to train international and professional innovative and entrepreneurial talents for the ASEAN region. Whether the curriculum of entrepreneurship education with curriculum as the core and teaching activities as the carrier is scientific and reasonable will directly affect the quality of entrepreneurial talents training in colleges and universities. It is of great significance to study the curriculum of entrepreneurship education for cultivating innovative talents, improving the quality of education and serving the regional economy. This paper explores the curriculum development of entrepreneurship education in guangxi universities by means of literature method, integration and analysis of network resources, theory and practice. It is found that there are still some problems in the development of entrepreneurship education in guangxi colleges and universities.
\end{abstract}

Keywords: entrepreneurship education, higher education, entrepreneurship education curriculum

\section{广西高等院校创业教育课程发展探究}

陈献宁 $1, \mathrm{a}$ 李德华 $2, \mathrm{~b}^{*}$

\footnotetext{
1 梧州学院商学院, 万秀区, 梧州, 广西, 中国

2 梧州学院团委, 万秀区, 梧州, 广西, 中国

a983426649@qq.com

b*492600953@qq.com
}

\begin{abstract}
摘要
广西作为面向东盟的第一区与东盟各国的经贸投资联系越来越频繁，伴随着中国-东盟自由贸易区的建 立，未来广西发展对人才的需求将更加向创新型人才倾斜。我们有必要为东盟地区培养国际化、专业 化的创新创业人才。以课程为核心, 以教学活动为载体的创业教育课程设置是否科学合理, 将会使高 校创业人才培养的质量直接受到影响。研究创业教育课程问题, 对于培养创新人才, 提高教育质量, 服务于区域经济具有重要意义。本文通过文献法、整合分析网络资源、理论联系实际的研究方法, 对 广西区内高校的创业教育课程发展进行了探究, 发现广西高等院校创业教育发展仍然存在着一些课程 培养目标与内容趋于同化且单一、双师型教师的缺乏等问题, 联合广西高校实际, 提出了三点对策来 优化创业课程: 以需要定目标, 杜绝僵化的目标、加大创业课程中双师型教师的投入、将地方特色融 入专业创业课程，优化课程的内容等方式。
\end{abstract}

关键词：创业教育，高等院校，创业教育课程 


\section{1. 前言}

清华大学举办创业大赛, 在 1998 年将创业活动推 向高潮, 拉开了大学创业教育的序幕。1999 年我国提出 高等教育的基本目标必须以培养学生创业能力和创业 精神为重点。教育部决定于 2002 年在清华大学、上海 交通大学、北京航空航天大学等 9 所高校开展创业教育 试点。自那以后, 越来越多的学者认识到开展创业教育 的必要性, 创业教育研究的成果也逐步增多。《国务院 办公厅关于深化高校创业教育改革的实施意见》提出, 对大学生创业教育的改革要深化, 建立健全大学生创业 教学大纲体系。从 2016 年之后, 所有的高校都要开设 创新创业教育课程。在这种背景下, 高校开展创业教育 就显得十分必要。

目前, 学术界对创业教育的定义仍有不同看法, 但 是所有的定义都从微观层面与宏观层面进行了界定, 主 要可归纳为三类: 一是创业人才培养目标, 强调实践、 突破和创新; 二是创业素质培养的最终目的, 强调多学 科的渗透与融合, 强调对全体学生的综合教育; 三是把 创业人才既掌握理论知识, 又有实践能力, 促进学生全 面发展的两种观点统一起来。本文综合以上观点, 认为 创业教育课程是指以现代教育思想和理念为指导, 以实 现培养目标为向导, 对学生进行意识、素质以及技能等 方面的教培工作 ${ }^{[1]}$ 。

“创新是民族进步的灵魂, 是振兴民族的不竭动 力。” 人才, 特别是创新人才的培养, 对经济发展、科 技进步至关重要。现代高等教育具有人才培养、科学研 究、文化传承、社会服务等多种功能。培养高素质人才 是高等教育适应现代社会改革的主题和目标。双创教育 课程设置是否科学合理, 直接关系到创新人才培养目标 的实现。因此, 本文选取了该课题进行研究。

\section{2. 高校创业教育课程现状与问题}

近几年来, 创业教育在高等教育改革中的关注度被 不断提高, 高等教育改革的日渐深入, 创业教育课就像 是一颗初升的太阳, 课程设置也受到了人们的关注。本 文以广西高校创业教育课建设为例, 通过资料的整理与 分析, 采访了创业教育工作者、创业课程教师等。深入 了解创业教育专业人士的基本观点, 阐述了目前课程设 置的现状和存在的问题。研究结果表明, 广西普通本科 院校创业教育课程设置取得了一定成效, 但也存在以下 问题。

\section{1. 创业教育课程培养目标不明朗、趋于同化}

我国高等教育的培养目标长期受制于传统的应试 教育理念, 注视知识的掌握和技能的培养, 注重对现实 社会环境的被动适应, 而忽视了人才的主观能动性和创 造性, 这一问题一直未得到重视。很多大学不明确创业
教育的课程目标, 只根据课程内容讲授创业基础知识, 完成教学任务。创业教育课程目标与广西高等院校课程 目标的趋同化表现在两个层面上: 一是同一所学校不同 专业的课程目标趋同。考察学校发现, 针对全校学生的 创业教育选修课侧重创业理论知识, 注重创业基础知识 的掌握, 忽视学生的差异性和专业特殊性, 课程目标缺 乏层次关系; 二是不同学校的课程教学目标逐渐相同。 社会需求、学校定位、专业特点等因素影响着课程设置, 因此, 课程目标应该具体化。目前创业教育的课程主要 是提高创业者的创业率, 缓解就业压力。创业教育课程 却没有考虑专业需求、学校定位, 缺乏特色、校本化。

表 1 广西 3 所高校的创业课程目标

\begin{tabular}{|c|l|l|}
\hline 学校 & \multicolumn{1}{|c|}{ 课程名 } & \multicolumn{1}{|c|}{ 培养目标 } \\
\hline $\mathrm{A}$ 校 & $\begin{array}{l}\text { 《大学生创业基础》 } \\
\text { 《大学生创业案例分析》 }\end{array}$ & $\begin{array}{l}\text { 培养学生的创 } \\
\text { 新精神和实践 } \\
\text { 能力 }\end{array}$ \\
\hline $\mathrm{B}$ 校 & 《创新创业》 & $\begin{array}{l}\text { 以提高学生创 } \\
\text { 新创业能力为 } \\
\text { 目标 }\end{array}$ \\
\hline $\mathrm{C}$ 校 & 《创业团队组建与管理》 & $\begin{array}{l}\text { 让学生掌握创 } \\
\text { 业基本技能 }\end{array}$ \\
\hline
\end{tabular}

\section{2. 师资力量结构的不平衡}

目前广西高校创业教育课程专任教师较少，大多为 兼职教师。就职业结构而言, 大多数教师都有教育或管 理专业背景，或曾从事过指导就业等方面的工作，而成 功知名企业家和创业导师才是学生们所期待的创业指 路人。但是就目前创业实践中的教师而言, 主要有辅导 员、就业指导教师、商学院教师, 以及一些兼职教师, 他们的教学方式多是填鸭式讲授, 教学的内容甚至与课 本一字不差。目前具有创业专业理论知识和实践经验的 高素质的双师型创业教师是广西高校创业教育课程建 设所急需的。我们都知道, 优良的教师队伍对于保证教 学质量很有必要。但是, 随着不断深入开展的创业教育, 教师无论是从数量上还是从质量上都难以满足高校创 业教育的需要, 成为创业教育发展的瓶颈。

\section{3. 创业课程内容发展的单一化}

教会学生们怎样创业是第一步, 更重要的是要培养 他们拥有创业家的基本素质，以他们对未来岗位的创新 服务能力。采访调查发现, 目前广西普通本科院校创业 教育课程内容单一化表现为偏重创业理论灌输缺乏创 业实践活动, 从全国的大视角看也是如此。创业教育课 程局限于专业理论知识的教授, 知识面窄, 灵活性差, 更未形成自身特色。同时, 缺乏与专业课程的整合, 忽 视了学科间的渗透; 课程没有激发大学生的创业创新精 神, 也没有立足行业发展动态, 达不到提高创业教育效 
果和培养质量。

一是只顾着填输知识, 缺乏实践性的互动。只是停 留在理论层面上是远远不够的, 会让学生对创业不再有 兴趣。实际需要理论的指导。创业教育要求学生具备一 定的管理实践基础, 了解创业管理的基本方法和政策法 规。

二是创业教育课程缺乏学科渗透与联系专业课程。 创业教育的课程不能体现各学科的专业特点, 不能联系 各行业的发展规律, 只传授一般的创业知识, 缺乏个体 的创业指导。当前, 广西创业教育课程覆盖范围相对有 限, 尤其缺乏对文史专业, 如历史学、艺术学等的关注。

\section{3. 广西高校创业课程的优化策略}

创业教育是个庞大的工程, 需要多方位的维护。一 个好的创业教育课程改革应结合广西当地特色和各校 办学的实际需要, 根据社会发展的需要, 明确自己的课 程目标, 优化课程内容, 根据专业特点, 从多方面综合 考虑, 改善课程结构, 提升教学的服务质量, 不断优化 教师团队的结构, 进行科学管理。

\section{1. 以需要定目标, 杜绝僵化的目标}

创业教育课程对于个人而言能够提高综合素质, 实 现个人价值; 对社会而言能够缓解就业压力, 促进我国 生产力发展, 建设创新型国家具有重要的现实意义。建 立课程目标, 首先要对创业教育有正确的理解。创业教 育课程目标的制定应包括教培、技能、教学的目标等, 把学生的兴趣和爱好纳入到考虑范围中、以及专业差异 和潜能素质, 注重导向性和激励性, 制定全面、灵活、 多元的课程目标, 为适应社会发展需要培养具有个性的 创新创业人才。创业知识、精神和能力的培养应该包含 在广西高校创业教育课程目标当中。知识目标的主要任 务是传授创业知识, 开阔创业的视野。精神目标是激发 大学生创业意识, 丰富学生的创业精神世界; 能力目标 包括专业、综合能力、灵活变通能力培养与提升。

\section{2. 在创业课程中加大双师型教师的投入}

开展教育, 尤其是创业教育, 必须加大投入 “双师 型” 教师，实行 “双轨制” 管理模式。“双师型” 教师 是指热爱创业教育, 具备一定的理论知识、实践经验和 管理能力, 或具有包含实践、理论教学的双重素养。“双 轨制” 是指管理创业教育教师应该分为全职和兼职两种 模式。根据发达国家办学经验, 构建创业教育课程师资 队伍, 要优化教师队伍结构, 提高教学质量, 必须加强 理论教学和实践教学。要从师资队伍建设上提高教师的 实践能力, 同时引进各学科的教师进行创业教育研究, 吸引社会上的成功企业家、科技精英、企业家等到校园 中来, 培养专业化、复合型创业教育师资, 打造国际化、 专业化、高水准的创业教育者。

\section{3. 将地方特色融入创业课程, 优化课程的内 容结构}

教学目的决定教学内容, 教学目的服务于教育。创 业教育的课程目标应该是多层次的, 但以培养创业家精 神和提高创业综合素质为主要内容。因此创业教育的课 程内容应是管理学、心理学等多学科的有机结合, 以培 养学生的动手实践能力。广西高校创业教育课程设置应 根据区域产业发展的现状与规律, 融入民族特色, 紧密 结合文、理、工、艺等专业特点, 培养学生的创业能力。 利用学科知识, 结合行业发展趋势, 开展创业辅导和创 新教育。构建具有行业和地方特色的创业教育教学体 系, 并根据不同学科门类的专业特点, 具体设置不同学 科如教育学、音乐表演等创业教学课程, 以补充和完善 现在创业教育的课程内容, 构建具有行业和地方特色的 创业教育教学体系。

\section{4. 结语}

成功实施广西高校的创新创业教育, 有利于培养高 修养的大学创新创业人才从而达到服务广西经济发展、 推动广西-东盟自由贸易区建设、推进 “一带一路” 建 设的目的。本研究通过调查走访, 分析广西高校创业教 育课程设的现状及问题，发现我区的创业教育的课程主 要存在以下问题: 课程目标的趋同、师资力量结构的不 平衡、创业课程内容发展的单一化。针对目前存在的问 题, 提出了三点优化路径: 以需要定目标, 杜绝僵化的 目标、加大创业课程中双师型教师的投入、将地方特色 融入专业创业课程, 优化课程的内容等方式。

\section{项目基金}

本文为广西高校思想政治教育质量提升 工程项目《“大思政”格局下梧州学院实践育 人创新模式探索与实践》的阶段性成果之一。

本文为广西高校中青年教师科研基层能 力提升项目 《认知与激情视角下大学生创业教 育对商机识别影响研究》 (2020KY17024) 的阶 段性成果之一。

本文为广西高校大学生思想政治教育理 论与实践研究项目 《“大思政” 格局下高校共 青团组织实践育人机制研究》 (2019MSZ022) 的阶段性成果之一。

本文为梧州学院校级科研项目项目《高校 共青团在创新人才培养中的机制研究一以梧 
州学院为例》 (2018B008) 的阶段性成果之一。

\section{REFERENCES}

[1] Wang Y. (2017) Study on the Present Situation of Entrepreneurship Education Curriculum in Guangxi General Undergraduate Colleges. Guangxi Normal University.

[2] Li N. (2018) Research on Innovation and Entrepreneurship Education of College Students majoring in Management. Guangxi Normal University,

[3] Ma X. Ecological Transformation of University Entrepreneurship Education. Beijing: Economic Science Press, 2015.

[4] Zang Lingling. (2016) A Study on College Entrepreneurship Education Curriculum from the International Perspective. China Social Sciences Press, Beijing.

[5] Lin M. (2016) Construction of the Curriculum System of College Students' Entrepreneurship Education in the Age of Mu-Class. Journal of Chongqing Jiaotong University, 2: 89-93.

[6] Fan P. (2014) A Study on Entrepreneurship Education for Undergraduate Students. Huazhong Agricultural University.

[7] Li J. (2013) A Study on the Mechanism of Entrepreneurship Education on College Students' Entrepreneurship Intention. Nankai University.

[8] Wu B. (2004) Construction of Practice Teaching System of Snow under the Background of Popular Education. Higher Education Exploration, 20(2): 45.

[9] G. T. Solomon, Duffy, Tarabishy. (2002) The state of entrepreneurship education in the United States: A nationwide survey and analysis. International Journal of Entrepreneurship Education.

[10] Robinson, P, Haynes, (1991) M. Entrepreneurship education in America $\mathrm{s}$ major universities. Entrepreneurship Education and Practice, 153: 41-52.

[11] Gartner, W. B. \&Vesper, K. H. (1994) Executive forum: Experiments in entrepreneurship education: Successes and failures. Journal of Business Venturing, 9: 179-187. 